\title{
Intermediate services' impact on capital goods production
}

\author{
Contribuição dos serviços intermediários na produção de bens de capital
}

\begin{abstract}
The literature on intermediate services has shown that this sector contributes to industrial competitiveness and productivity rises. The production frontier is used to determine whether intermediate services contributed to the growth of capital goods production in the period between 1995 and 2009. The results found corroborate the hypothesis that the greater use of inputs from the sector results in an increase in the capital goods production in developed countries and indicate that this relationship is much weaker for developing countries. The growth of the capital goods sector's productivity depends on the emergence of a growing symbiotic relationship between intermediate services and new communication technologies. The presence of these services helps to explain the greater dynamism of the capital goods sector in developed countries.
\end{abstract}

\section{Keywords}

intermediate services, production frontier, capital goods.

JEL Codes L6, L8, O4.

\author{
Adilson Giovanini (1) \\ Wallace Marcelino Pereira (2) \\ Kleverton Clóvis de Oliveira Saath ${ }^{(3)}$ \\ (1) Universidade do Estado de Santa Catarina \\ (2) Universidade Federal de Minas Gerais \\ (3) Universidade Federal de Santa Catarina
}

\section{Resumo}

A literatura de serviços intermediários mostra que este setor contribui para o aumento da competitividade e da produtividade industrial. A fronteira de produção é utilizada para determinar se os serviços intermediários contribuíram para o crescimento da produção de bens de capital no período entre 1995 e 2009. Os resultados obtidos corroboram a hipótese de que a maior utilização de insumos oriundos deste setor resulta em aumento da produção de bens de capital nos países desenvolvidos, sendo esta relação mais fraca para os países em desenvolvimento. O crescimento da produtividade do setor de bens de capital depende do surgimento de uma relação de crescente "simbiose" entre os serviços intermediários e o ingresso nas novas tecnologias de comunicação. A presença destes serviços o que ajuda a explicar o maior dinamismo daquele setor nos países desenvolvidos.

\section{Palavras-chave}

serviços intermediários, fronteira de produção, bens de capital.

Códigos JEL L6, L8, O4. 


\section{Introduction}

The capital goods sector is transversal to other industrial activities. It is responsible for supplying other sectors with the production means that they need. Productivity gains and innovation in this sector spread to others. This feature is the reason why it is considered to be a driving force for economies (MARSON, 2008).

The central role of the capital goods sector as a supplier of machines to other sectors causes its features to be reflected in national indexes of productivity and competitiveness. This sector contributes to the rise in productivity of other sectors. On the other hand, countries where the capital goods sector is not innovative and has low productivity are also countries with low international competitiveness as a result of the low level of productivity of other industrial activities (HITOMI, 1994; MARSON, 2008; ROSENBERG, 1963).

There is growing evidence that the economic growth and productivity gains created by the industry after the 1970s can be explained by the emergence of intermediate services, especially new communication technologies. ${ }^{1}$ In the past decades, such technologies have been responsible for carrying other sectors' technical progress, putting them at the same level of importance as the capital goods sector (CASTELLACCI, 2008).

According to Morrow et al. (2010), the contribution of new communication technologies and intermediate services varies among industrial activities. Watanabe (2015) argued that the literature on the subject lacks studies seeking to identify the influence of such services on specific industrial activities. Brynjolfsson and Mcafee (2014) showed that the capital goods sector has been profoundly altered by new communication technologies and that there is a relatively large literature on advanced manufacturing and Industry 4.0. They argued that the emergence of new service-intensive technologies ${ }^{2}$ is drastically affecting industry. However, we did not find any studies showing the specific contributions of different service activities to capital goods production.

1 Aboal and Tacsir (2018), Campos and Calandro (2008), Cruz-Moreira and Fleury (2003), Francois and Woerz (2008), Hesseldahl (2010), Linden et al. (2009), Lodefalk (2014), Nordås and Kim (2013), Tempest (1996) e Vu (2013).

2 The literature on this topic, although recent, is vast. Here are some of the many articles on the topic: Fengque (2017), Georgakopoulos (2016), Michahelles (2017), Niggemann and Beyerer (2016) and Schuh (2015). 
Given the high transversality of capital goods activities and their strategic role as a driving force for other activities, a specific study is required to determine whether service activities influence the capital goods production capacity. Our hypothesis is that the expansion of the capital goods sector's production frontier depends on the presence of specific intermediate services and that there is a direct and positive relationship between them.

The existence of intermediate services is a distinctive feature of developed countries, and it contributes to these nations' competitiveness. On the other hand, the low development of intermediate services in developing countries hinders the emergence of adequate conditions for the development of the capital goods sector, jeopardizing these countries' production growth.

We used the stochastic frontier production function model developed by Aigner et al. (1977), Battese and Coelli (1995) and Meeusen and Van Den Broeck (1977) to measure the contribution of intermediate services to capital goods production. We used annual data from the World Input-Output Database for 33 countries, between 1995 and 2009, with a sample of 495 observations. We chose this sample based on the countries' relevance to the world economy and the size of their capital goods sector, given the data availability.

Besides this introduction, this paper has four sections. In the next section, we present a historical review of the literature on intermediate services. In section 3 , we describe our data and the methodology used to estimate the production frontier. Section 4 contains the results. Finally, in the last section, we make some final considerations.

\section{Evolution of the theoretical framework about ser- vices}

The theoretical body and the debate about the service sector has an important contribution from Baumol (1967), who sought to understand the service sector and its relationship with the industrial sector. His ideas about this subject are known as "cost disease". He claimed that the growth in the service sector implies lower productivity of the economy due to the replacement of a dynamic sector (industry) with a less dynamic sector (services). Services have a lower level of productivity; however, the salaries in 
this sector are consistent with the wages of the other sectors, leading to an increase in production costs and economic stagnation.

After the 1970s and 1980s, the consequences of the emergence of the paradigm of information and communication technologies (ICT) and research and development $(\mathrm{R} \& \mathrm{D})$ activities in the service sector were discussed. Summers (1985) showed that service expenditures increased proportionally more than the increase in nominal income. Roach (1988) found evidence that, since the 1980s, the capital stock in the service sector, mainly ICT, has started to show higher growth rates than the other sectors. In addition, Browning and Singelmann (1978) presented a new classification for the sector, distinguishing it into intermediate services (those used by companies) and final services (those demanded by consumers).

The studies conducted since the 1990s have been carried out amid the reversal of the growth rates of the American economy and the consolidation of services as essential to the globalization process, in the sense that they reduce transport costs and increase energy infrastructure and aggregation of value. ${ }^{3}$ This can be approached through the global value chain (GVL) literature. Studies in this area have shown that, since the 1970s, competition between multinational companies has led to a process of redistribution of activities according to each country's advantages, which has resulted in developed countries specializing in services and developing countries specializing in manufacturing activities, linked to the assembly process of industrial products. ${ }^{4}$

This phenomenon can be explained by the fragmentation of production, which refers to the process through which the productive dynamics happens in different companies, each specializing in specific activities of the GVLs (FLÔRES JÚNIOR, 2010). According to Carneiro (2015), the division of production into a larger number of stages increases productivity but creates the need to coordinate the activities of the various agents involved, and the complexity of coordination increases with an increase in the number of steps into which the production is divided. The optimal number of steps depends on the trade-off between the gains obtained

3 Arbache (2014), Berlingieri (2013), Di Cagno and Meliciani (2005), Francois and Woerz (2008), Guerrieri and Meliciani (2005); Linden et al. (2009); Oliveira and Von Hippel (2011), Unctad (2013) and Unesco (2015).

4 Bernhofen et al. (2016), Copeland (2013), Corrêa (2016), Evans and Annunziata (2012), Iapadre and Memedovic (2010), Nordås (2008), Milberg and Winkler (2013), Miles (2008), Sarti and Hiratuka (2010) and Unctad (2013). 
from the specialization and the costs incurred by the coordination of the work (BALDWIN; LOPEZ-GONZALEZ, 2013).

That being said, services contributed to the reduction of trade costs from the 1980s through the development of transportation systems and the containerization of products as well as the development of new communication technologies. ${ }^{5}$ The result was scattered international productive organization of goods and services in value chains, with specialization of firms and countries no longer in the exporting of different products but in different manufacturing and service activities (such as design, logistics and marketing), which provoked the rise of foreign direct investment flows (CARNEIRO, 2015).

As pointed out by ARAUJO JÚNIOR (2013), the increase in the relative importance of services can be explained by the vertical specialization process. Whenever a company outsources or acquires inputs that were previously produced internally, new activities are generated, not only for the supplier of these inputs but also for the providers of different services, such as transportation, insurance and financial intermediation.

This is a hierarchy, at the top of which is the firm that owns the brand, with greater qualification and greater conditions of value capture. Following it are the local producers, which are responsible for some stages of product development and physical production; these can be divided into first- and second-tier suppliers (ERNST, 2005; ERNST; KIM, 2001).

First-tier suppliers have specific strategic assets and specific skills that are difficult to replicate (brand, technology and market knowledge), which give the leading company the control over the process, the establishment of negotiation parameters, the format of contracts and the quality standards to be followed by the other participants in the chain. These assets are in such areas as design review, prototype building, pilot production and mass production, that is, R\&D (SARTI; HIRATUKA, 2010). Second-tier suppliers have advantages only in mass production and standardized activities.

As pointed out by Nonnenberg (2013), the transition from mass production to first-tier supplier demands high investments in the transfer and $a b-$ sorption of technology and in workers' qualification. This is achieved only

5 The service literature began to incorporate a Neo-Schumpeterian approach to explain the contribution of services to economic growth. For more details, see: Ahmed (2017), Francois and Woerz (2008), Freeman and Soete (2008), Franke and Kalmbach (2005), Lodefalk (2014), Marsh (2012), Nordås (2008) and Nordås and Kim (2013). 
by firms that can develop internal competencies that allow the mastery of strategic technological processes, the absorption of new technologies and dialogue on an equal basis with the firms that hold the knowledge. Thus, countries where companies are brand owners and, to a lesser degree, are first-tier suppliers capture a greater proportion of the value generated by global chains. On the other hand, countries that fail to develop these strategic assets remain in a lower position, capturing a smaller proportion of the value generated in these chains. ${ }^{6}$

The 1990s ushered in a new phase in international economic dynamics. In view of the rise in data processing complexity, the development of software and applications and the expansion of communication dynamics, Bell and Pavitt (1997) created the term "information intensive", which includes all services linked to financial activities, retail, publications and telecommunications. The increasing interactivity between consumer and service provider led Buzzacchi et al. (1995) to indicate the need to study the different forms of service provision, ranging from the integration of supply chains to integrated logistics services, especially regarding the activities linked to knowledge-intensive services.

The evolution of the service sector caused Oulton (2001) to question Baumol's (1967) "cost illnesses" hypothesis. Taking the classification proposed by Browning and Singelmann (1978), these authors argued that the "cost disease" occurs only if the productivity growth in the industry results in a rise in the participation of the final services in the added value.

However, an increase in services' share in the value added does not occur through the growth of final services' share. What we actually see is a decrease in the participation of the latter and an increase in the participation of intermediate services. Given that these services are used as inputs by industry, small growth rates in their productivity are enough to increase the productivity of the economy. The literature on knowledgeintensive services (KIBSs) has stated that these provide the industry with the necessary knowledge and contribute to the generation of innovations in the industrial sector. In many cases, industrial innovations only occur in the presence of intermediate services (HERTOG, 2000; MILES, 2008; MILES et al., 1994, 1995; MULLER; ZENKER, 2001).

6 Campos and Calandro (2008), Cruz-Moreira and Fleury (2003), Gereffi and Frederick (2010), Hesseldahl (2010), Linden et al. (2009), Nonnenberg (2013), Shih (1992) and Tempest (1996). 
Recent evidence has shown that intermediate services are also subject to Kaldor's laws. These services have economies of scale and are able to generate self-sustained income growth (DASGUPTA; SINGH, 2007; DI MEGLIO et al., 2015; GIOVANINI; AREND, 2017).

Another growing stream of research has analysed the participation of services in industry, of which it is worth highlighting the taxonomy created by Castellacci (2008). This taxonomy considers the service-industry interaction, contemplating how this interaction contributes to the emergence of innovations. According to Arbache (2014), services are assuming increasing importance in explaining economic dynamics.

Two trends explain the increase in the interrelationship between services and industry: 1) the rise in the share of services and 2) the outsourcing of business-related services, such as research and development, financing and logistics. An analysis for the OECD (Organization for Economic Co-operation and Development) countries revealed that the share of services has increased in all industrial sectors except for oil refining (NORDÅ, 2008).

As a result, the breakdown of final goods sold to consumers in services and industry is increasingly inadequate, since a growing quantity of products is sold in "packages" incorporating physical production and services symbiotically. This applies especially to the most technologically advanced products, which have a greater amount of services incorporated into their final value (ARBACHE, 2015).

In this sense, intermediate services can be divided into two groups, namely: 1) value services and 2) cost services. Value services include activities that add value to production, resulting in an increase in the market price, productivity and return on capital. Cost services influence the competitiveness of firms and increase production efficiency but do not result in product differentiation or an increase in the sales value (ARBACHE, 2014; PILAT, WÖLFL, 2004).

The importance of cost services and value services varies with products and depends on the interaction between services and industry (PILAT; WÖLFL, 2004). Cost services are more important to ensure competitiveness for industrial sectors that produce commoditized products that are more homogeneous, being found in developing countries. Value services, in turn, are more important in developed countries, in which it is possible to achieve product differentiation, that is, the capital goods sector (MOREIRA, 2015; UNCTAD, 2013; UNESCO, 2015). 
In addition, the participation of services as an intermediate input of industry varies between countries. Industrial activities are more dependent on the service sector as a supplier of intermediate inputs than other economic activities (ACEMOGLU et al., 2007; NORDÅS, 2008). Thus, the increasing share of services as an intermediate input for industry means that the appropriate allocation of services exerts ever-greater influence on industrial productivity. In this sense, unproductive and low-quality services result in more expensive finished goods of poorer quality. The absence of adequate intermediate services may inhibit and even prevent the manufacturing of industrial products. ${ }^{?}$

More recently, the literature on advanced manufacturing and Industry 4.0 has stated that the emergence of new service-intensive technologies (cyber-physical systems, the Internet of Things, 3D printers and intelligent systems) will contribute to the dynamism and growth of industrial productivity. The development of these technologies will profoundly affect the industrial sector and depend on the ability of countries to develop sophisticated service activities. ${ }^{8}$

\section{Manufacturing production and the intermediate service sector in the international scenario}

The left panel in Figure 1 shows the share of services in the total trade for each country. All the countries accounting for more than $25 \%$ of services in total exports are developed countries, India and Japan being the only exceptions, with $29 \%$ and $23 \%$ in 2016 . Among the developing countries, Australia, Brazil and Russia stand out, with shares of 23\%, 23\% and 21\% in the same year, respectively. The share of the other Asian countries' services in the total trade was minimal. In 2016, the share of South Korea, China and Indonesia was only $18 \%, 16 \%$ and $16 \%$, respectively. All countries' share of services in the total trade grew in the analysed period, India, Italy, Indonesia, South Africa and Turkey being the only exceptions.

Given the marketable nature of modern services, it is possible to measure relatively well the degree of development of these services in a coun-

7 Amiti et al. (2005), Berlingieri (2013), Francois and Woerz (2008) and Nordås (2008).

8 Fengque (2017), Georgakopoulos (2016), Michahelles (2017), Niggemann and Beyerer (2016) and Schuh (2015). 
try. The data show that China's development process is distinct from that of South Korea. China's industrial development occurs in parallel with an increase in the share of the service sector in its total trade, which has a small share in world trade but grew significantly between 2005 and 2016 from $12 \%$ to $16 \%$.

Figure 1 Services' share in the total trade per country (\%) (A) and machinery and equipment production of the 13 largest producers (billion US\$) (B)

A

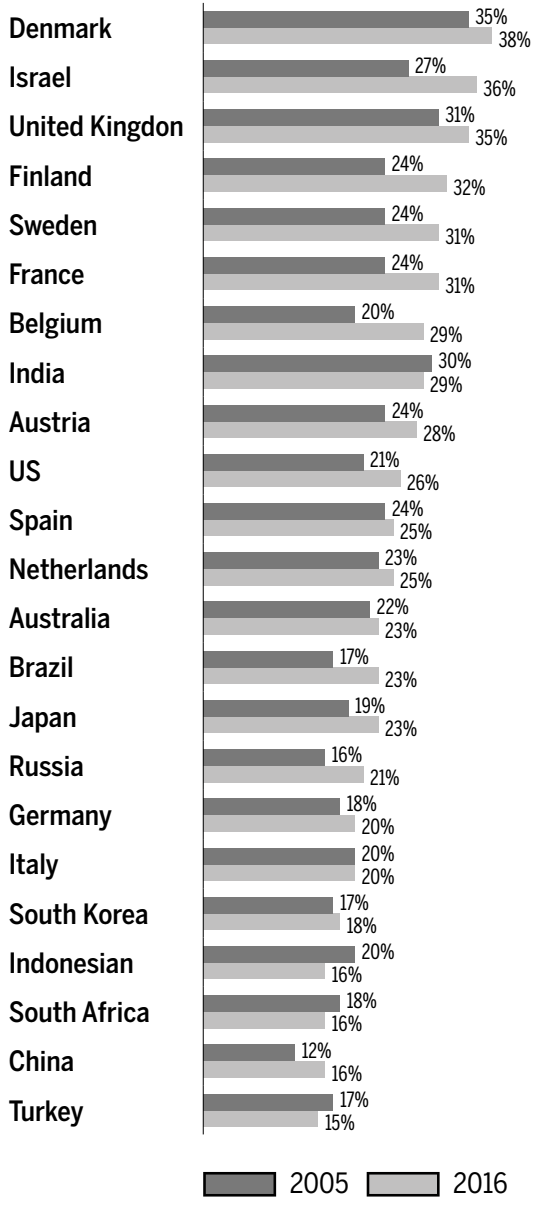

B
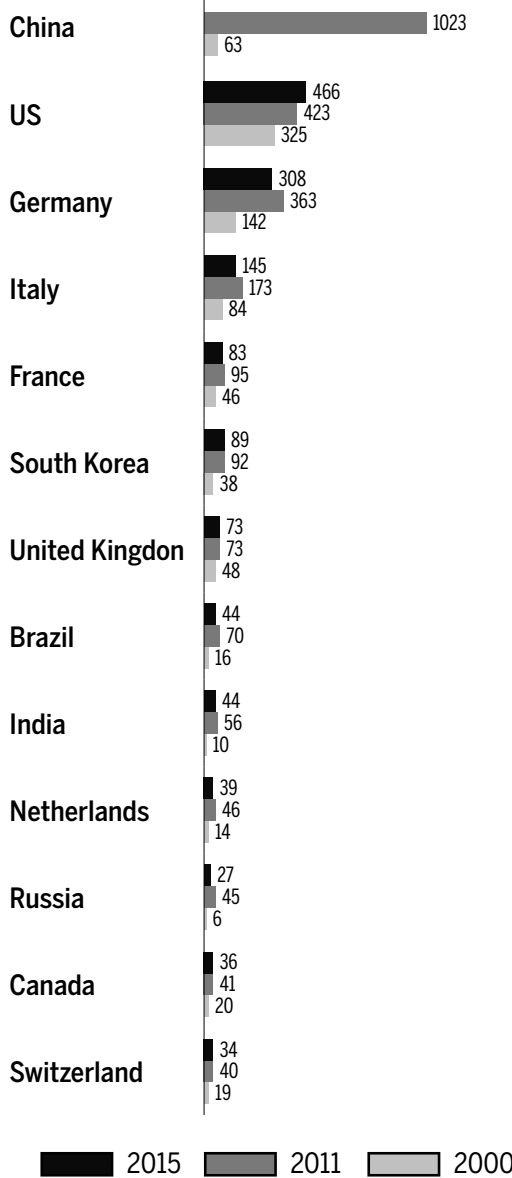

Source: UNIDO.

The right panel in Figure 1 shows the production of machinery and equipment of the 13 largest producers in the years 2000, 2011 and 2015. The 
data compiled in this figure show the growth of Chinese production at the expense of most other countries. In 2011, it was the largest producer of machinery and equipment, at US $\$ 1,023.00$ billion, followed by the United States and Germany, with US $\$ 466.00$ billion and US $\$ 308.00$ billion in 2015, respectively. In the period from 2011 to 2015, only four countries reported no decline in production, namely Singapore, the United States, Turkey and the United Kingdom, with average annual growth of $4 \%, 2 \%$, $1 \%$ and $0 \%$, respectively.

Table 1 Inputs used by the machinery and equipment sector in 2009 , average index number $(1995=100)$

\begin{tabular}{lr}
\hline Input & Index number \\
\hline Machinery and equipment production & 159 \\
\hline Water transportation & 240 \\
\hline Mail and telecommunications & 224 \\
\hline Health care & 222 \\
\hline Air transportation & 202 \\
\hline Public administration & 200 \\
\hline Rent M\&E & 157 \\
\hline Accommodation & 155 \\
\hline Average high & 147 \\
\hline Other services & 147 \\
\hline Electricity & 145 \\
\hline Domestic services & 138 \\
\hline Construction & 138 \\
\hline Average low & 134 \\
\hline Education & 131 \\
\hline Auxiliary transport activities & 129 \\
\hline Sale, maintenance and repair of motor vehicles and motorcycles; sale of fuel & 128 \\
\hline Real estate activities & 118 \\
\hline Wholesale & 114 \\
\hline Ground transportation & 111 \\
\hline Retail & 111 \\
\hline Primary inputs & 102 \\
\hline Financial intermediation & 90 \\
\hline Sour &
\end{tabular}

Source: World Input Output Database. 
The data show that the share of Asian countries in the world production of manufactured products has grown. This movement has been accompanied by the production of ICT and machinery and equipment. However, the analysis of the data on service trade shows that these countries still have low service exports, which are concentrated in developed countries.

Table 1 shows the index number $(1995=100)$ for each input amount used by the machinery and equipment sector in $2009 .{ }^{9}$ The inputs that registered the highest growth were water transportation, with an index number equal to 240 in 2009, followed by mail and telecommunication, 224, and health and social work, 222. Air transport, public administration and rental of machinery and equipment follow, with 202, 200 and 157 , respectively.

In sum, the only input of which the use shrank was financial intermediation. These data show that the services of ICT, transport and rental of machines and equipment are among those that presented greater accumulated input growth.

\section{Data and statistical procedure}

\subsection{Our data}

Table 2 shows the data used to perform the above estimation. Obtaining sector-by-sector data was a major challenge, since traditional sources, such as Groningen, do not provide a broad sample of disaggregated data for the intermediate service sector. The solution was to use data extracted from the World Input-Output Database (TIMMER, 2015), as this source provides disaggregated data for 33 sectors and 40 countries. All intermediate inputs considered were deflated by the intermediate input inflation indicator, provided by the World Input-Output Database (TIMMER, 2015). The year 1995 was defined as the basis.

9 According to Farias (2015), the index number is calculated as follows: $I_{t}=\frac{V A_{t}}{V A_{b}}$, where $V A$ is the value added, $I_{t}$ is the index for period $t$ and $b$ is the base period. 
Table 2 Indexes

\begin{tabular}{|c|c|c|}
\hline Name & Description & Source \\
\hline VA & $\begin{array}{l}\text { Gross value added of the capital goods sector at } \\
1995 \text { prices }\end{array}$ & World Input-Output \\
\hline K & Real fixed capital stock of the capital goods sector & \\
\hline $\mathbf{L}$ & Total hours worked in the capital goods sector & World Input-Output \\
\hline Industry & Quantity of inputs from industry* & World Input-Output \\
\hline Value & $\begin{array}{l}\text { Mail and telecommunications; financial intermedia- } \\
\text { tion; rental of M\&Eq and other business activities* }\end{array}$ & World Input-Output \\
\hline Cost & $\begin{array}{l}\text { Land transportation; water transportation; air trans- } \\
\text { portation; other supportive and auxiliary transport } \\
\text { activities; travel agency activities* }\end{array}$ & World Input-Output \\
\hline PuA & $\begin{array}{l}\text { Public administration and defence; compulsory } \\
\text { education; social security; health and social work }\end{array}$ & World Input-Output \\
\hline Others & $\begin{array}{l}\text { Electricity, gas and water supply; construction; } \\
\text { sale, maintenance and repair of motor vehicles } \\
\text { and motorcycles; sale and retail of fuel; wholesale } \\
\text { and commission trade, except motor vehicles and } \\
\text { motorcycles; retail, except motor vehicles and } \\
\text { motorcycles; repair of household goods; hotels and } \\
\text { restaurants; real estate activities; other community, } \\
\text { social and personal services; private households } \\
\text { with employed persons* }\end{array}$ & World Input-Output \\
\hline ICT & Mail and telecommunications* & World Input-Output \\
\hline Inflation & Gross value added price level & Penn World Table 9.0 \\
\hline Inflation deviation & Brazilian inflation subtracted from US inflation & Penn World Table 9.0 \\
\hline $\begin{array}{l}\text { Government } \\
\text { consumption }\end{array}$ & Government consumption as a percentage of GDP & Penn World Table 9.0 \\
\hline Exchange rate & $\begin{array}{l}\text { Relative exchange rate, base: } 1995 \text { United States } \\
\text { exchange rate }\end{array}$ & Penn World Table 9.0 \\
\hline $\begin{array}{l}\text { Sophistication } \\
\text { of exports }\end{array}$ & Level of sophistication of exported goods & Penn World Table 9.0 \\
\hline H & Human capital index & Penn World Table 9.0 \\
\hline
\end{tabular}

Source: Compiled by the authors.

Note: * Used as intermediate inputs by the capital goods sector.

To understand better how intermediate services affect the production of capital goods, four regressions were estimated through two distinct sectorial and spatial cuts. Initially, the sample was divided into two sets: developed countries (Austria, Canada, Germany, Denmark, Spain, Finland, 
France, Ireland, Italy, Japan, the Netherlands, Portugal, Sweden and the United States) and developing countries (Australia, Brazil, Cyprus, the Czech Republic, Estonia, Greece, Hungary, India, Latvia, Mexico, Malta, Poland, Russia, Slovenia and Turkey). One of the limitations of this methodology was the need for a large sample of observations, which required the addition of Eastern European countries, which have the least expressive capital sector.

Once the spatial cut had been defined, the next step was to establish the two sectorial cuts that we used. The first cut disaggregated the 35 economic activities into 6 categories: industry, which includes all industrial activities; cost services; value services; public administration; and other service activities. The activity of mail and telecommunications was not grouped with any other, and we considered it as a variable in the estimated model.

For the second sectorial cut, we estimated a model with the lowest possible aggregation of activities. As the sample had a limited size, it was not possible to estimate regressions for all activities, and it was necessary to resort to aggregation again. Industrial activities were aggregated into two categories: 1) medium-low ${ }^{10}$ and medium-high ${ }^{11}$ technological intensity activities and 2) five service activities, which were aggregated in the item "other activities". ${ }^{2}$ This cut allowed the identification of specific service activities' effect on the production of capital goods.

\subsection{Statistical procedure}

The capital goods sector's production function is obtained using the stochastic frontier production method, proposed by Aigner et al. (1977). This method was improved and later used by Battese and Coelli (1995):

$$
\ln Y_{i t}=\alpha_{1}+\alpha_{2} \ln K_{i t}+\alpha_{3} \ln L_{i t}+\sum_{l=1}^{n} \alpha_{l} \ln I_{l, i t}+u_{i t},
$$

10 Food, beverage and tobacco; textiles and clothing; leather and footwear; wood and wood and cork products; pulp, paper, printing and publishing; coke, refined petroleum and nuclear fuel.

11 Chemicals; rubber and plastics; other non-metallic minerals; basic metals and produced metal; machines and equipment; electrical and optical equipment; transportation equipment; recycling.

12 Hotels and restaurants; administration and public defence; health and social work; other community, social and personal services; private households with employees. 
where $Y_{i t}$ is the capital goods sector's value added of country $i$ in period $t$, in millions; $K_{i t}$ is the stock of physical capital of country $i$ in period $t$ for the capital goods sector, in billions; $L_{i t}$ is the number of hours worked in the capital goods sector in country $i$ in period $t ; I_{1, i t}$ is a vector of intermediary inputs defined according to the two sectorial cuts described in the previous subsection; $\alpha_{i}$ is constant; and $u_{i t}$ is the error term.

\section{Results of the estimated models}

Table 3 shows equation (1)'s estimated coefficients for aggregate activities. The results indicate that the capital factor is significant at the $90 \%$ confidence level for developed countries. A change of $1 \%$ in the amount of capital employed results in a change of $0.333 \%$ in the production of capital goods. This result confirms the importance of capital, which is the variable with the highest coefficient.

Table 3 Estimated coefficients for aggregated activities according to the service classification

\begin{tabular}{l|rrrrr}
\hline & \multicolumn{2}{|c|}{ Developed countries } & \multicolumn{2}{r}{ Developing countries } \\
\cline { 2 - 5 } & Coefficient & Standard error & Coefficient & Standard error \\
\hline ICT & $0.123^{*}$ & 0.027 & -0.018 & 0.044 \\
\hline Industry & $0.373^{*}$ & 0.084 & 0.005 & 0.046 \\
\hline Cost services & -0.050 & 0.105 & $-0.339^{*}$ & 0.107 \\
\hline Value services & $0.385^{*}$ & 0.050 & $0.267^{*}$ & 0.045 \\
\hline $\mathrm{K}$ & $0.828^{*}$ & 0.011 & $0.891^{*}$ & 0.013 \\
\hline $\mathrm{L}$ & $-0.440^{*}$ & 0.052 & $0.076^{*}$ & 0.025 \\
\hline Others & 0.044 & 0.058 & $0.134^{* *}$ & 0.068 \\
\hline Public administration & $-0.280^{*}$ & 0.049 & -0.047 & 0.032 \\
\hline Constant & 0.155 & 0.198 & $1.096^{*}$ & 0.294 \\
\hline
\end{tabular}

Source: Compiled by the authors.

Note: * Significant at $90 \% ;{ }^{* *}$ Significant at $95 \%$.

The estimated coefficient for the labour factor indicates that the increase in value added exerts a negative influence on the production of developed countries. Indeed, the capital goods sector is capital intensive and labour input is expensive in these countries, making it possible to in- 
crease production in the sector by replacing labour with capital (FUGLIE et al., 2013).

Intermediary inputs from industry are significant at the $95 \%$ confidence level. An increase of $1 \%$ in these inputs results in an increase of $0.373 \%$ in value added. This result is in accordance with our a priori expectations, evidencing that the increase in production demands adequate industrial inputs. Similarly, value services are significant and have a positive effect on the value added in the capital goods sector, indicating that the greater use of these services results in an increase in value added.

On the other hand, cost services are not statistically significant, not influencing the value added in the capital goods sector. This result endorses the research by UNCTAD (2013) and UNESCO (2015), which showed that developed countries produce more sophisticated industrial goods that are sensitive to the presence of value services but are not very sensitive to cost services. Public administration as an input has a negative influence on the production of capital goods, so greater use of these services reduces the capital goods sector's value added.

Furthermore, the estimated coefficient for the ICT sector is significant and positive, indicating that a $1 \%$ variation in the amount of this input used results in a variation of $0.12 \%$ in the value added. As seen, since the advent of microelectronics, the capital goods sector has demanded more and more inputs from the service sector. According to Melo (1998), the propagation of microelectronics is leading to the substitution of inputs from industry and agriculture with intermediate services. According to Alem and Pessoa (2005), microelectronics have a strong influence on the production of the capital goods sector, which causes technical progress. The development of this sector demands the emergence of specialized services (MELO, 1998).

These inputs not only enter into production factors but also interact with the production process itself, changing the ways in which transactions are carried out and goods are produced (BRYNJOLFSSON; HITT, 2000). The ICT sector induces transformations in organizational processes and the automation of industrial administrative practices, contributing to the growth in the production of this sector (HERTOG, 2000).

The estimated production function highlights the importance of intermediate services and new communication technologies for the capital goods sector in developed countries. Greater use of service sector inputs 
results not only in higher production but also in higher quality goods, which are reflected in higher added value (NORDÅS, 2008; SHIH, 1992).

Therefore, the contribution of the service sector as an input supplier for the capital goods sector is a competitive differential. The high values found for the estimated coefficients corroborate this assertion: increases in the amount of intermediate inputs used related to value services result in an increase in value added. That is, they result in greater value aggregation.

The results found for developing countries, shown in columns four and five of Table 3 , indicate that the capital factor has a strong influence on the value added of capital goods. A $1 \%$ increase in the amount of this factor used results in an increase of $0.891 \%$ in the value added.

As these countries have an abundance of workers, the production technology is more intensive in this factor. An increase of $1 \%$ in the workforce results in growth of $0.076 \%$ in added value. Given that the capital goods sector is capital intensive, the low contribution of the labour factor to production is stressed compared with an increase of the same magnitude in the quantity of the capital factor used.

On the other hand, the greater use of cost services results in lower production. As this type of activity is composed mainly of transport activities, these results indicate limitations in the provision of transport in developing countries. The presence of low transport costs is a competitive differential, so an increase in transport costs leads to a reduction in value added. As highlighted by Lesher and Nordås (2006), countries where manufacturers have access to transport, telecommunications, electricity and quality financial services show greater product differentiation, making them more resistant to economic fluctuations. On the other hand, countries that are deficient in providing these services are less competitive.

Mulder (2017) showed that cost services in developing countries generally have higher prices, which have a negative impact on their industrial competitiveness. These higher prices are associated with lower productivity, lower competition and lower investment.

For developing countries, industry and public administration are not statistically significant, so the amount of these inputs does not seem to influence the added value. ICT services are also not statistically significant, indicating that the new communication technologies do not contribute to the increase in production. These results are in agreement with the evidence found in the service literature, which showed that develop- 
ing countries have only partially adopted the new communication technologies. ${ }^{13}$ Products manufactured in these countries are more cost and service intensive, and the low presence of value services compromises the production of more sophisticated products. ${ }^{14}$ Thus, the lower competitiveness of developing countries is explained by the lower presence of intermediate services (HARRY; LIANG, 2018; ROBERTS, 2011; VOSKOBOYNIKOV, 2017).

The results also show that the capital goods produced in developed countries are different from those manufactured in developing countries. In the latter, capital goods are more sensitive to value services and are more sophisticated industrial goods, which depend on these services to a greater extent. On the other hand, developing countries are less sensitive to value services. While value services continue to affect production in these countries, indicating that the capital goods sector is influenced by value services, their lower presence may jeopardize the development of the capital goods industry.

According to WATANABE (2015), the ability of ICTs to stimulate economic growth depends on the state of technology and the investment in this technology by each country. ICTs have a positive effect only if appropriate policies are in place. Their lower contribution to the production of developing countries is explained by the shortage of skilled workers and by the absence of the institutions necessary for the further development of this sector (CHINN, FAIRLIE, 2010; MORROW et al., 2010; PAGANETTO, 2017; TIMMER; VAN ARK, 2005). These countries need to implement policies aimed at automation, the qualification of their workers in new technologies and the adoption of digital technologies (CADENA et al., 2017; HOFMAN et al., 2017).

In addition, Frischtak (2017) argued that the "use of new technologies" is a growing problem in developing countries, as users have access to these technologies but are unable to explore their potential. For Frischtak (2017), the development of new communication technologies depends on initiatives to improve the trade environment; modernization of transport

13 Arbache (2014), Berlingieri (2013), Di Cagno and Meliciani (2005), Francois and Woerz (2008), Guerrieri and Meliciani (2005), Linden et al. (2009), Lodefalk (2014), Moreira (2015), Nordås and Kim (2013) and Oliveira and Von Hippel (2011).

14 Copeland (2013), Corrêa (2016), Evans and Annunziata (2012), Sarti and Hiratuka (2010), Iapadre and Memedovic (2010), Nordås (2008), Milberg and Winkler (2013), Miles (2008), Sarti and Hiratuka (2010), UNCTAD (2013) and UNESCO (2015). 
and physical and "flexible" infrastructure (commercial logistics and regulations); increased competition in the provision of services; and high-quality internet access (in terms of speed and stability) that is universal, accessible, open and secure.

Thus, the results found help to fill the gap identified by Watanabe et al. (2015), who showed that there are still few studies that have examined the contribution of services to increasing productivity in specific sectors. These results are also in tune with the new evidence found in the KIBS literature, which showed that intermediate services provide knowledge for the industrial sector, contributing to innovations in products but especially in processes. The results show that the addition of services to the capital goods sector contributes to the growth of production. These services are not considered to be traditional inputs but act on the production process as a whole, modifying it to make it more efficient and productive.

Table 4 presents the results obtained for the estimated regressions for intermediate inputs, broken down by service activity. The results for the developed countries show that an increase in the amount of capital, $K$, results in an increase in the value added; the same is true for the inputs from the medium-low and medium-high technological intensity industries. On the other hand, greater use of primary inputs and labour results in a reduction in value added. This result is consistent with the argument that the capital goods sector is capital intensive, so greater use of the labour factor represents allocation inefficiency, which negatively affects production.

The estimated coefficients for the inputs from the service sector - electricity, construction and transportation - have statistically significant values but a negative sign. As these services are more related to cost services, their greater use may represent an increase in costs, reflecting these countries' lower competitiveness. For example, greater use of electricity may be related to less efficient technologies or higher costs, which may result in lower production.

The transportation support activities are related to logistics services, so greater use of these services may result in greater efficiency in the acquisition of inputs and in the sale of final goods. Thus, an increase in the consumption of these services increases efficiency in production and ensures greater coverage of the consumer market, resulting in greater production. The estimated coefficient for trade also shows a positive sign, contributing to the increase in production. 
Table 4 Estimated coefficients for disaggregated activities

\begin{tabular}{lrrrrr}
\hline & \multicolumn{2}{|c|}{ Developed countries } & \multicolumn{2}{r}{ Developing countries } \\
\cline { 2 - 5 } & Coefficient & Standard error & Coefficient & Standard error \\
\hline $\mathrm{K}$ & $0.836^{*}$ & 0.013 & $0.909^{*}$ & 0.015 \\
\hline Primary & $-0.419^{*}$ & 0.071 & $0.082^{*}$ & 0.018 \\
\hline Medium-low & $-0.236^{*}$ & 0.111 & -0.049 & 0.074 \\
\hline Medium-high & $0.478^{*}$ & 0.183 & 0.099 & 0.079 \\
\hline Electricity & $0.520^{*}$ & 0.135 & $-0.087^{* *}$ & 0.050 \\
\hline Construction & $-0.261^{*}$ & 0.058 & $-0.042^{*}$ & 0.042 \\
\hline Trade & $-0.179^{*}$ & 0.075 & $0.078^{*}$ & 0.060 \\
\hline Transportation & $0.161^{*}$ & 0.066 & $0.195^{*}$ & 0.043 \\
\hline Transportation support & $-0.325^{*}$ & 0.080 & $-0.198^{*}$ & 0.040 \\
\hline ICT & $0.217^{*}$ & 0.058 & $-0.073^{*}$ & 0.031 \\
\hline Financial intermediation & $0.240^{*}$ & 0.037 & $-0.201^{*}$ & 0.042 \\
\hline Rent & $0.153^{*}$ & 0.038 & $0.075^{*}$ & 0.028 \\
\hline Education & 0.065 & 0.071 & $0.090^{* *}$ & 0.054 \\
\hline Other services & -0.015 & 0.061 & $0.127^{*}$ & 0.044 \\
\hline Constant & $-0.242^{*}$ & 0.095 & -0.028 & 0.027 \\
\hline & -0.191 & 0.399 & -0.026 & 0.193 \\
\hline
\end{tabular}

Source: Compiled by the authors.

Note: * Significant at 90\%; ** Significant at 95\%.

The greater presence of these services translates into the construction of more efficient trade channels, greater value aggregation, greater customization, better after-sales services, greater efficiency in the approach to and identification of consumer needs and more adequate and efficient product availability, which contributes indirectly to the increase in production.

ICT and financial intermediation services also have a positive sign, indicating that the greater use of these services results in greater production. On the other hand, the estimated coefficient for rental services of machines and equipment and other business services (rental) is not statistically significant. The use of these services does not contribute to the increase in production in this cut. Likewise, the estimated coefficient for education is not statistically significant.

For developing countries, capital and labour are again statistically significant and have a positive effect on production. However, among industrial inputs, only medium-high technology inputs contribute to the increase 
in production. The increase in consumed electricity, transportation and transport support results in a decrease in production.

Once more, we argue that greater consumption of these services may indicate the presence of deficiencies in their supply, which negatively affects the country's competitiveness, resulting in lower production. On the other hand, greater use of construction and trade services results in higher production, which may be associated with the construction of new production units or the expansion of existing ones and the constitution of more efficient marketing and after-sales strategies and channels.

These results show that developing countries' greater consumption of financial intermediation, machines and equipment rental and other business services (rental) and education also results in greater production. Capital goods manufacturing units have high-scale production, so the presence of adequate financial intermediation services represents a favourable element in the collection of the necessary resources. As these products usually have a higher sales value, financial services can also imply greater flexibility in payment methods, which facilitates their commercialization. Developing countries have technological limitations. Accordingly, the need to acquire specialized services for the leasing of machinery and equipment and business services arises. The greater use of these services contributes to the increase in production. The same is true for continuing education services, considering that they help to reduce workers' technical disabilities.

Moreover, the greater consumption of ICT services results in a decrease in production. As highlighted by the service literature, developing countries' adoption of new communication technologies has happened only partially. In these countries, these services are expensive and of low quality, so greater use, instead of contributing to the advance of production, has the opposite effect.

As pointed out by NORDÅS (2008), having a relatively broad base of service providers at a relatively low cost is associated with the existence of a large domestic market for these services, better technologies for their manufacture and few barriers to entry. The greater number of suppliers also contributes to cost reduction associated with the acquisition of intermediate services.

In general, the estimated results show that developing countries lack intermediate services. The low participation of these countries in new communication technologies and the high price of services aggravate this 
situation, raising production costs. The result is an environment that is less conducive to the production of capital goods. Given the cross-cutting nature of this sector, its lower development may result in lower competitiveness of other industrial sectors as well.

\section{Final remarks}

The contribution of the service sector to economic development and to the industrial sector's competitiveness has, for many years, been neglected by the economic literature. This article presents different ways in which the service sector contributes to countries' productivity and competitiveness.

Here, we present three different arguments. First, the use of inputs from the service sector implies a qualitative change in the characteristics assumed by the goods produced. The greater use of intermediate services results in goods with higher quality and higher added value, which can be sold at higher prices to final consumers. In this way, countries that have a more developed intermediate service sector have greater participation in the value added in global value chains (SHIH, 1992). Second, technologically more sophisticated goods use larger amounts of intermediate services in their production, especially services related to innovation. Third, the emergence of new communication technologies has raised the amount of services used in the manufacture of industrial products.

These three arguments converge in the same idea: countries with the most developed intermediate service sectors, in general, produce higherquality goods sold with higher value added. They also tend to innovate more and produce more technologically sophisticated goods. Consequently, the intermediate service sector positively influences countries' competitiveness and economic growth capacity.

The international context has shown that manufacturing production is migrating to Asia, mainly to China. A similar movement is apparent in the capital goods sector. However, service activities are still concentrated in developed countries, despite China's service and ICT sectors' growing share in its total trade and its exports, respectively.

Our estimated regressions for the capital goods sector confirmed the hypothesis. Intermediate services influence countries' production capacity. The high values found for the estimated coefficients are in accordance 
with the "smiling curve". A change in the amount of services used as an input results in a change in the value added of the capital goods sector. ICT services influence developed countries' productive capacity, so the development of this sector can contribute to greater competitiveness of the capital goods industry.

On the other hand, the greater use of cost services contributes to lower production of capital goods in developing countries. This evidence supports the argument that the presence of lower-quality cost services, provided at higher prices, may jeopardize the competitiveness of the capital goods sector.

The results found support our hypothesis: the amount of intermediate services used helps to explain the value added of the capital goods sector. The presence of better-quality intermediate services contributes to the greater competitiveness of developed countries. On the other hand, the incipient development of the intermediate service sector in developing countries does not strengthen the capital goods sector in such countries, which may jeopardize their production. The implementation of specific policies that promote the further development of the intermediate service sector and the ICT sector may result in the expansion of production in the capital goods sector.

\section{References}

ABOAL, Diego; TACSIR, Ezequiel. Innovation and productivity in services and manufacturing: the role of ICT. Industrial and Corporate Change, v. 27, n. 2, p. 221-241, 2018.

ACEMOGLU, D. et al. Technology, information, and the decentralization of the firm. Quarterly Journal of Economics, v. 122, n. 4, p. 1759-1799, 2007.

AHMED, E. M. ICT and human capital spillover effects in achieving sustainable East Asian knowledge-based economies. Journal of the Knowledge Economy, v. 8, n. 3, p. 1086-1112, 2017.

AIGNER, D.; LOVELL, C. A. K.; SCHMIDT, P. Formulation and estimation of stochastic frontier production function models. Journal of Econometrics, v. 6, n. 1, p. 21-37, 1977.

ALEM, A. C. D. de; PESSOA, R. M. O setor de bens de capital e o desenvolvimento econômico: quais são os desafios? BNDES Setorial, Rio de Janeiro, n. 22, p. 71-88, set. 2005.

AMITI, M. et al. Fear of service outsourcing: is it justified? Economic Policy, v. 20, n. 42, p. 307-347, 2005.

ARAUJO JÚNIOR, J. T. A. Fragmentação da produção e competitividade internacional: o caso 
brasileiro. Breves Cindes, Rio de Janeiro, n. 73, abr. 2013.

ARBACHE, J. Dinâmica recente da conta de transações correntes e a conta de serviços. Disponível em SSRN: https://ssrn.com/abstract=2443043; http://dx.doi.org/10.2139/ ssrn.2443043. 2014.

ARBACHE, J. Produtividade nos serviços. In: De Negri, F. (Org.); Cavalcante, L. R. (Org.) Produtividade no Brasil desempenho e determinantes, Volume 2. IPEA, Brasília, p. 277-300, 2015.

BALDWIN, R.; LOPEZ-GONZALEZ, J. Supply chain trade: a portrait of global patterns and several testable hypotheses. Working Paper, n. 18.957. Washington: NBER, 2013.

BATTESE, G. E.; COELLI, T. J. A model for technical inefficiency effects in a stochastic frontier production function for panel data. Empirical Economics, v. 20, n. 2, p. 325-332, 1995.

BAUMOL, W. J. Macroeconomics of unbalanced growth: the anatomy of urban crisis. American Economic Review, v. 57, n. 3, p. 415-426, 1967.

BELL, M.; PAVITT, K. Technological accumulation and industrial growth: contrasts between developed and developing countries. Technology, Globalisation and Economic Performance, v. 83137, p. 83-137, 1997.

BERLINGIERI, G. Essays on international trade and firm organization. Tese (PhD). Londres: Department of Economics of the London School of Economics, dez. 2013.

BERNHOFEN, D. M.; EL-SAHLI, Z.; KNELLER, R. Estimating the effects of the container revolution on international trade. Journal of International Economics, Elsevier, v. 98C, p. 3650, 2016.

BROWNING, H. L.; SINGELMANN, J. The transformation of the US labor force: the interaction of industry and occupation. Politics \& Society, v. 8, n. 3-4, p. 481-509, 1978.

BRYNJOLFSSON, E.; HITT, L. M. Beyond computation: information technology, organizational transformation and business performance. Journal of Economic Perspectives, p. 23-48, 2000.

BRYNJOLFSSON, E.; MCAFEE, A. The second machine age: work, progress, and prosperity in a time of brilliant technologies. Norton \& Company, Washington, 2014.

BUZZACCHI, L.; COLOMBO, M. G.; MARIOTTI, S. Technological regimes and innovation in services: the case of the Italian banking industry. Research Policy, v. 24, n. 1, p. 151-168, 1995.

CADENA, A. et al. Where will Latin America's growth come from? McKinsey Global Institute, San Francisco, 2017.

CAMPOS, S. H.; CALANDRO, M. L. Nova configuração do mercado de trabalho internacional de calçados e os impactos sobrea indústria calçadista gaúcha. In: IV Encontro de Economia Gaúcha - EEG, Porto Alegre, 2008.

CARNEIRO, F. L. Fragmentação internacional da produção e cadeias globais de valor. Texto para Discussão. Instituto de Pesquisa Econômica Aplicada (IPEA), Brasília, 2015.

CASTELLACCI, F. Technological paradigms, regimes and trajectories: manufacturing and service industries in a new taxonomy of sectoral patterns of innovation. Research Policy, v. 37, n. 6-7, p. 978-994, 2008.

CHINN, M. D.; FAIRLIE, R. W. ICT use in the developing world: an analysis of differences 
in computer and internet penetration. Review of International Economics, v. 18, n. 1, p. 153$167,2010$.

COPELAND, E. Identifying the potential of logistics technology. Supply Chain Digital, available at: https://www.supplychaindigital.com/supplychaindigital/about_us, access in: march, 10, 2018.

CORRÊA, L. M. Nas trajetórias dos países em desenvolvimento. Tese de Doutorado. Universidade Federal do Rio de Janeiro, Rio de Janeiro, 2016.

CRUZ-MOREIRA, J.; FLEURY, A. Cadeias de produção de roupas em Honduras e no Brasil: uma comparação em termos do progresso industrial. In: XXIV Congresso Internacional da Associação de Estudos Latino-Americanos, 2003.

DASGUPTA, S.; SINGH, A. Manufacturing, services and premature deindustrialization in developing countries: a Kaldorian analysis. In: MAVROTAS, G.; SHORROCKS, A. (Eds) Advancing development. Palgrave Macmillan, p. 435-454, 2007.

DI CAGNO, D., MELICIANI, V. Do inter-sectoral flows of services matter for productivity growth? An input/output analysis of OCDE countries. Economics of Innovation and New Technology, v. 14, n. 3, p. 149-171, 2005.

DI MEGLIO, G. et al. Services in developing economies: a new chance for catching-up? SWPS 2015, n. 32. Disponível em SSRN: https://ssrn.com/abstract=2744647; http://dx.doi.org/10. 2139/ssrn.2744647. 2015.

ERNST, D. The new mobility of knowledge: digital information systems and global flagship networks. In: LATHAM, R.; SASSEM, S. (Eds). IT and new architectures in the global realm. Princeton University Press, Princeton, 2005.

ERNST, D.; KIM, L. Global production networks, knowledge diffusion and local capability formation. A conceptual framework. Working Papers, n. 19. Honolulu, USA: East-West Center, 2001.

EVANS, P. C.; ANNUNZIATA, M. Industrial internet: pushing the boundaries of minds and machines. General Electric, 2012.

FARIAS, A. M. Li. de. Métodos estatísticos aplicados à economia i: números índices. Departamento de estatística - Universidade Federal Fluminense. Disponível em: http://www.est. uff.br/images/ArqGET/EnsMatDidat/get00117_II-0.pdf. Acesso em: 19 set. 2018. 2015.

FENGQUE, P. et al. Research on design of the smart factory for forging enterprise in the industry 4.0 environment. Mechanics, v. 23, n. 1, p. 146-152, 2017.

FLÔRES JÚNIOR, R. G. A fragmentação mundial da produção e comercialização: conceitos e questões básicas. In: ALVAREZ, R.; BAUMANN, R.; WOHLERS, M. (Eds). Integração produtiva: caminhos para o Mercosul. Série Cadernos da Indústria, v. 16. Brasília: ABDI, 2010.

FRANCOIS, J.; WOERZ, J. Producer services, manufacturing linkages, and trade. Journal of Industry, Competition and Trade, v. 8, n. 3-4, p. 199-229, 2008.

FRANKE, R.; KALMBACH, P. Structural change in the manufacturing sector and its impact on business-related services: an input-output study for Germany. Structural Change and Economic Dynamics, v. 16, n. 4, p. 467-488, 2005.

FREEMAN, C.; SOETE, L. A economia da inovação industrial. UNICAMP, Campinas, 2008.

FRISCHTAK, C. R. Industries without smokestacks: telecommunication and ICT-based services trade. 
WIDER Working Paper. Helsinki: UNU-WIDER, 2017.

FUGLIE, K. O. et al. Productivity growth in agriculture: an international perspective. European Review of Agricultural Economics, v. 40, n. 3, p. 531-534, July 2013.

GEORGAKOPOULOS, D. et al. Internet of Things and edge cloud computing roadmap for manufacturing. IEEE Cloud Computing, v. 3, n. 4, p. 66-73, 2016.

GEREFFI, G.; FREDERICK, S. The global apparel value chain, trade and the crisis: challenges and opportunities for developing countries. Policy Research working paper, n. 5281, Washington, 2010.

GIOVANINI, A.; AREND, M. Contribution of services to economic growth: Kaldor's fifth law? RAM. Revista de Administração Mackenzie, v. 18, n. 4, p. 190-213, 2017.

GUERRIERI, P.; MELICIANI, V. Technology and international competitiveness: the interdependence between manufacturing and producer services. Structural Change and Economic Dynamics, v. 16, n. 4, p. 489-502, 2005.

HARRY, X.; LIANG, D. T. Accounting for the role of information and communication technology in China's productivity growth. In: Productivity Dynamics in Emerging and Industrialized Countries. Routledge India, p. 331-362, 2018.

HERTOG, P. D. Knowledge-intensive business services as co-producers of innovation. International Journal of Innovation Management, v. 4, n. 4, p. 491-528, 2000.

HESSELDAHL, A. The iPad: more than the sum of its parts; $\$ 270$ more, actually. Bloomberg Business Week, v. 22, p. 24, 2010.

HITOMI, K. Automation - its concept and a short history. Technovation, v. 14, n. 2, p. $121-$ 128, 1994.

HOFMAN, A. et al. Sources of productivity and economic growth in Latin America and the Caribbean, 1990-2013. International Productivity Monitor, v. 33, p. 51-76, 2017.

IAPADRE, L.; MEMEDOVIC, O. Structural change in the world economy: main features and trends. United Nations Industrial Development Organization (UNIDO), Viena, 2010.

LINDEN, G.; KRAEMER, K.; DEDRICK, J. Who captures value in a global innovation system? The case of Apple's iPod. Communications of the ACM, v. 52, n. 3, p. 140-144, 2009.

LODEFALK, M. The role of services for manufacturing firm exports. Review of World Economics, v. 150, n. 1, p. 59-82, 2014.

MARSH, P. The new industrial revolution: consumers, globalization and the end of mass production. Yale University Press, Yale, 2012.

MARSON, M. D. A indústria de bens de capital no processo de industrialização na década de 1930: crescimento e diversificação no estado de São Paulo. Revista Economia, Brasília, v. 9, p.577-599, 2008.

MEEUSEN, W.; VAN DEN BROECK, J. Efficiency estimation from Cobb-Douglas production functions with composed error. International Economic Review, p. 435-444, 1977.

MELO, H. P. de et al. O setor serviços no Brasil: uma visão global-1985/95. Texto para discussão n. 549. IPEA, Brasília, 1998.

MICHAHELLES, F. et al. IoT 2016. IEEE Pervasive Computing, v. 16, n. 2, p. 87-89, 2017. 
MILBERG, W.; WINKLER, D. Outsourcing economics: global value chains in capitalist development. Cambridge University Press, New York, 2013.

MILES, I. Patterns of innovation in service industries. IBM Systems Journal, v. 47, n. 1, p. 115, 2008.

MILES, I. et al. Knowledge-intensive business services: their role as users, carriers and sources of innovation. European Commission, Brussels, 1995.

MILES, I. et al. Knowledge intensive business services: their roles as users, carriers and sources of innovation. Manchester: PREST, 1994.

MOREIRA, R. F. C. Descentralização da produção e produtividade no Brasil. Dissertação (Mestrado em Economia). Brasília: Universidade de Brasília, 2015.

MORROW, K. M. C. et al. Determinants of TFP growth: a close look at industries driving the EU-US TFP gap. Structural Change and Economic Dynamics, v. 21, n. 3, p. 165-180, 2010.

MULDER, N. Unlocking Latin America's export potential in final and intermediate services: the definition of a research agenda using new statistics. Sabbatical Report. Economic Commission for Latin America and the Caribbean, Rotterdam, 2017.

MULLER E., ZENKER, A. Business services as actors of knowledge transformation: the role of KIBS in regional and national innovation systems. Research Policy, v. 30, n. 9, p. 1501-16, 2001.

NIGGEMANN, O.; BEYERER, J. (Ed.). Machine learning for cyber physical systems: selected papers from the International Conference ML4CPS 2015. Springer, Lemgo, 2016.

NONNENBERG, M. J. B. Integração produtiva, fragmentação da produção e evolução do comércio internacional: como evoluíram os países da Ásia e América Latina? Texto para Discussão. Instituto de Pesquisa Econômica Aplicada (IPEA), Brasília, 2013.

NORDÅS, H. K. The impact of services trade liberalisation on trade in non-agricultural products. OECD Trade Policy Papers, 81. OECD Publishing, Paris, 2008.

NORDÅS, H. K.; KIM, Y. Interaction between goods and services trade: case studies. OECD Trade Policy, Papers, n. 148, OECD Publishing, Paris. 2013.

OLIVEIRA, P.; VON HIPPEL, E. Users as service innovators: the case of banking services. Research Policy, v. 40, n. 6, p. 806-818, 2011.

OULTON, Nicholas. Must the growth rate decline? Baumol's unbalanced growth revisited. Oxford Economic Papers, v. 53, n. 4, p. 605-627, 2001.

PAGANETTO, L. Knowledge economy, information technologies and growth. Routledge, England, 2017.

PILAT, D.; WÖLFL, A. ICT production and ICT use: what role in aggregate productivity growth? In: The economic impact of ICT: measurement, evidence and implications. OECD Publishing, Paris, 2004.

ROACH, S. S. Technology and the services sector: the hidden competitive challenge. Technological Forecasting and Social Change, v. 34, n. 4, p. 387-403, 1988.

ROBERTS, S. Measuring the impact of ICT for development. UNCTAD Current Studies on Science, Technology and Innovation, n. 3, United Nations, Geneva, 2011.

ROSENBERG, N. Technological change in the machine tool industry, 1840-1910. Journal of 
Economic History, v. 23, n. 4, p. 414-443, 1963.

SARTI, F; HIRATUKA, C. Indústria mundial: mudanças e tendências recentes. Texto para Discussão n. 186. IE/UNICAMP, Campinas, dezembro 2010.

SCHUH, G. et al. Promoting work-based learning through industry 4.0. Procedia CIRP, v. 32, p. 82-87, 2015.

SHIH, S. Millennium transformation: change management for new Acer. Aspire Academy Series, [s.d.]. Disponível em: http://www.stanshares.com.tw/StanShares/upload/tbBook/1_20100817144639.pdf. Acesso em: 01 dez. 2016. 1992.

SUMMERS, R. Services in the international economy. In: Inman, R. P. (Ed). Managing the service economy: prospects and problems. Cambridge University Press, p. 27-48, Cambridbe, 1985.

TEMPEST, R. Barbie and the world economy. Los Angeles Times, Los Angeles, 1996.

TIMMER, M. P.; VAN ARK, B. Does information and communication technology drive EUUS productivity growth differentials? Oxford Economic Papers, v. 57, n. 4, p. 693-716, 2005.

TIMMER, M. P. et al. An illustrated user guide to the World Input-Output Database: the case of global automotive production. Review of International Economics, v. 23, n.3, p 575-605, 2015 .

UNCTAD. World Investment Report 2013 - global value chains: investment and trade for development. Nova Iorque e Genebra: Nações Unidas, 2013.

UNESCO. UNESCO Institute for Statistics (UIS). Available in: http://www.uis.unesco.org/. access in: 23 Jan. 2019.2015.

UNIDO. United Nations Industrial Development Organization. Unido statistics data portal. Available in: https://stat.unido.org/?_ga=2.178665383.243032413.1584730193719945807.1584730193, access in: March 20, 2020.

VOSKOBOYNIKOV, I. Sources of long run economic growth of the Russian economy before and after the global financial crisis. Russian Journal of Economics, v. 3, n. 4, p. 348-365, 2017.

VU, K. M. Information and communication technology (ICT) and Singapore's economic growth. Information Economics and Policy, v. 25, n. 4, p. 284-300, 2013.

WATANABE, C. et al. New paradigm of ICT productivity - increasing role of un-captured GDP and growing anger of consumers. Technology in Society, v. 41, p. 21-44, 2015.

\section{About the authors}

Adilson Giovanini-adilson.giovanini@udesc.br

Universidade do Estado de Santa Catarina, Balneário Camboriú, Santa Catarina, Brasil.

ORCID: https://orcid.org/0000-0001-8948-1186.

Wallace Marcelino Pereira - wallacemp2000@yahoo.com.br

Centro de Desenvolvimento e Planejamento Regional, Universidade Federal de Minas Gerais, Belo Horizonte, Minas

Gerais, Brasil.

ORCID: https://orcid.org/0000-0003-1817-3332.

Kleverton Clóvis de Oliveira Saath-klevertonsaath@gmail.com

Universidade Federal de Santa Catarina, Florianópolis, Santa Catarina, Brasil.

ORCID: https://orcid.org/0000-0001-6862-9030. 
Giovanini, Pereira \& Saath

\section{About the article}

Submission received on December 17, 2017. Approved for publication on December 17, 2018. 